\title{
Cement Clinker Based on Industrial Waste Materials
}

\author{
Alpha Ousmane Toure ${ }^{1,2,3 *}$, Nicholas Auyeung ${ }^{2}$, Falilou Mbacke Sambe ${ }^{1}$, Jackson Scott Malace ${ }^{2}$ and Fuqiong Lei ${ }^{2}$ \\ ${ }^{1}$ Department of Chemical Engineering and Applied Biology, Cheikh Anta Diop University of Dakar, Ecole Superieure Polytechnique, Senegal \\ ${ }^{2}$ College of Engineering, School of Chemical Biological and Environmental Engineering, Oregon State University, Corvallis, USA \\ ${ }^{3}$ College of Engineering, School of Civil and Construction Engineering, Oregon State University, Corvallis, USA
}

\begin{abstract}
The manufacturing of cement consumes energy and results carbon dioxide emissions. This work focused on producing cement clinker using coal fly ash (CFA), sewage sludge ash (SSA) and an industrial waste with a high content of calcium silicate (CS). Experiments were conducted to assume the use of a process that may consume less energy and raw materials that used in cement clinker manufacturing. The raw mixtures were prepared with lower clay and limestone contents than those used in Portland clinker manufacturing and then burned at lower temperatures, ranged from 1000 to $1200^{\circ} \mathrm{C}$. Due to the content of fluxes and mineralizers of the raw mixtures, this method could decrease carbon dioxide emissions from calcination up to $60 \%$ and energy consumption up to $350 \mathrm{kcal} / \mathrm{kg}$ of clinker. The free lime content of the clinker was found out by volumetric analysis and was consistent with free lime content in Portland cement clinker. Activation energies ranged from 42.7 to $91.1 \mathrm{~kJ} / \mathrm{mol}$ and the cement clinkers contents of fluorine varied from 0.82 to $3.9 \%$. The main characterizations of the obtained clinker, which were X-ray fluorescence, X-ray diffraction and SEM, highlighted interesting composition as building material.
\end{abstract}

Keywords: Calcium silicate $\bullet$ Cement clinker $•$ Coal fly ash $\bullet$ Industrial waste $•$ Sewage sludge ash

\section{Introduction}

Ordinary Portland Cement (OPC) has been a priority material of construction used in many countries throughout the world. In 2017, approximatively 4,100 million metric tons of cement were produced worldwide [1]. Even though OPC is essential for construction and building purposes, its manufacturing process consumes high energy and generates carbon dioxide emissions; with the production of one ton of clinker producing 0.9 ton of $\mathrm{CO}_{2}$ emissions [2]. The main ingredients for obtaining OPC are limestone, iron, silica and alumina. Alternative raw materials are being used in order to reduce limestone and clay consumption and also energy requirement [3]. Several studies related the use of alternatives raw materials such as coal fly ash, sewage sludge ash and some fluoride waste. Indeed, sludge and coal from wastewater treatment and power plants constitute interesting raw materials for cement industry. Coal fly ash has been tested in order to manufacture belite cement [4]. The effect of sewage sludge ash on the properties of cement composites was a purpose of study as well as its cementitious properties $[5,6]$. Coal bottom ash was also confirmed to reduce material and energy consumption [7]. The use of a mixture of calcium silicate and calcium fluoride, as an industrial waste material from phosphoric acid production, in the raw mixture for clinker manufacturing was successful to produce a fluoride clinker [8] as well as the production of cement at low temperature [9]. In this study, three industrial waste materials were used: a calcium silicate compound (CS), coal fly ash (CFA) and sewage sludge ash (SSA). The objectives of this study were to:

- minimize the disposal of industrial waste from phosphoric acid production, wastewater treatment and coal power plant;

- examine if it is possible to lower energy and raw materials (limestone and clay) consumption in the cement manufacturing process.

*Address for Correspondence: Alpha Ousmane Toure, Department of Chemical Engineering and Applied Biology, Cheikh Anta Diop University of Dakar, Ecole Superieure Polytechnique, Senegal, College of Engineering, School of Chemical Biological and Environmental Engineering \& School of Civil and Construction Engineering, Oregon State University, Corvallis, USA, Tel: +775700730; E-mail: tourea@oregonstate.edu

Copyright: ๑ 2020 Toure AO, et al. This is an open-access article distributed under the terms of the creative commons attribution license which permits unrestricted use, distribution and reproduction in any medium, provided the original author and source are credited.

Received 08 May, 2019; Accepted 15 May, 2020; Published 22 May, 2020

\section{Materials and Methods}

This section highlights the raw materials, the mixtures, the burning process and the methods of cement clinker characterization.

\section{Raw materials}

\section{Limestone and kaolin clay}

The limestone ( $99 \mathrm{wt} \%$ of $\mathrm{CaCO}_{3}$ ) was provided by Omya Canada Inc. The kaolin clay was purchased by VWR Corporation and its chemical composition is shown in Table 1.

\section{Industrial waste materials}

Table 2 summarizes the chemical compositions of the three industrial waste materials which were used. The particle sizes of the raw materials are listed in the Table 3 . The CS was recovered from a process of caustification to obtain sodium hydroxide carried out in lab experiment. Actually, it is a material mainly composed of calcium silicate [10]. A class F CFA was used. The SSA was obtained from the calcination at $850^{\circ} \mathrm{C}$ of activated sludge provided by Corvallis Wastewater Plant (Oregon, USA).

\section{Raw mixtures preparation}

The five raw materials (limestone, kaolin, CS, CFA and SSA) were used for preparing the three raw mixtures containing three raw materials (Table 4). This preparation was definitely based on the standard values of the lime saturation factor (LSF) and the silica ratio (SR) factors as required in OPC production [11].

\section{Burning process}

After proper blending, the raw mixtures were crushed by means of a porcelain mortar and pestle and fired at the desired temperature during 30 min on an alumina crucible in a ST-1600C-445 Box furnace, with the program going to $10^{\circ} \mathrm{C}$ in $1 \mathrm{~min}$. Four temperatures were fixed for each raw mix to study the burning process (Table 5 ).

\section{Analytical methods}

The obtained clinkers were analyzed to determine the burnability and the chemical composition. X-ray fluorescence studies were performed on Epsilon 3 XLE (Malvern Panalytical Manufacturing). XRD was performed, using the D8-Discover (Bruker Manufacturer). The SEM analysis was handled by the QUANTA $600 \mathrm{~F}$ (Fei Company). The free lime contents of the clinkers (CaOL 
Table 1. Chemical composition of the kaolin.

\begin{tabular}{cccccc}
\hline Compound & $\mathrm{SiO}_{2}$ & $\mathrm{Al}_{2} \mathrm{O}_{3}$ & $\mathrm{TiO}_{2}$ & $\mathrm{LOI}_{2}$ \\
\hline Content (wt \%) & 51.70 & 43.20 & 2.03 & 0.10 \\
\hline
\end{tabular}

Table 2. Chemical composition of the industrial waste materials.

\begin{tabular}{|c|c|c|c|c|c|c|c|c|c|c|c|c|c|c|}
\hline Materials (\%wt) & $\mathrm{CaO}$ & $\mathrm{SiO}_{2}$ & $\mathrm{Al}_{2} \mathrm{O}_{3}$ & $\mathrm{Fe}_{2} \mathrm{O}_{3}$ & MgO & $\mathrm{K}_{2} \mathrm{O}$ & $\mathrm{SO}_{3}$ & $\mathrm{Mn}_{2} \mathrm{O}_{3}$ & $\mathrm{ZnO}$ & $\mathrm{Cl}$ & $\mathrm{TiO}_{2}$ & $\mathrm{Na}_{2} \mathrm{O}$ & $\mathrm{P}_{2} \mathrm{O}_{5}$ & LOI \\
\hline CS & 67.08 & 13.89 & 0.32 & 0.09 & 0.52 & 0.12 & 0.08 & 0.01 & 0.01 & 0.01 & 0.02 & 9.15 & 0.04 & 8.67 \\
\hline CFA & 16.79 & 44.31 & 15.5 & 6.01 & 5.05 & 1.56 & 0.93 & 0.1 & 0.02 & 0.01 & 0.95 & 3.45 & 0.24 & 5.08 \\
\hline SSA & 7.06 & 39.64 & 9.48 & 6.19 & 3.13 & 4.56 & 1.02 & 0.17 & 0.3 & 0.01 & 1.6 & 4.45 & 17.3 & 5.32 \\
\hline
\end{tabular}

Table 3. Particle sizes of the raw materials.

\begin{tabular}{cccccc}
\hline Material & Limestone & Kaolin & CS & SSA & CFA \\
\hline Particle size $(\mathrm{mm})$ & 4.43 & 1.50 & 6.82 & 6.61 & 63 \\
\hline
\end{tabular}

Table 4. Raw mixtures preparation (\% wt).

\begin{tabular}{|c|c|c|c|c|c|c|c|}
\hline RM (\% wt) & Limestone & Kaolin & CS & CFA & SSA & LSF & SR \\
\hline RM1 & 25 & 16 & 59 & 0 & 0 & 96.8 & 2.34 \\
\hline RM2 & 59 & 0 & 11 & 30 & 0 & 93.1 & 2.28 \\
\hline RM3 & 59 & 0 & 11 & 0 & 30 & 99.4 & 2.83 \\
\hline
\end{tabular}

Table 5. Temperatures of the burning process.

\begin{tabular}{cccc}
\hline & \multicolumn{3}{c}{ Temperatures $\left({ }^{\circ} \mathrm{C}\right)$} \\
\hline $950^{\circ} \mathrm{C}$ & $1000^{\circ} \mathrm{C}$ & $1050^{\circ} \mathrm{C}$ \\
\hline $1000^{\circ} \mathrm{C}$ & $1050^{\circ} \mathrm{C}$ & $1100^{\circ} \mathrm{C}$ \\
\hline $1050^{\circ} \mathrm{C}$ & $1100^{\circ} \mathrm{C}$ & $1100^{\circ} \mathrm{C}$ \\
\hline
\end{tabular}

in wt\%) were determined by means of the known volumetric ethylene-glycerol method. The analyzed results were compared with the chemical composition of Portland clinker as specified in ASTM C150-07 [12].

\section{Results and Discussion}

This section exhibits the experimental results of the burning process and the characteristics of the obtained cement clinker.

\section{Burning process}

The process of clinkerization at four temperatures was determined by following the free lime content. The results of the burning process are displayed in Figure 1.

The displayed results above highlighted the possibility to obtain good quality of clinker at temperatures lower than $1200^{\circ} \mathrm{C}$ in accordance with a free lime content ranged from 0.6 to $2 \%$. Three samples of clinker were obtained (CL1, CL2 and CL3) based on the content of free lime consistent with the maximum value. The first type of clinker CL1, from RM1, was produced at the lowest temperature (about $1000^{\circ} \mathrm{C}$ ). Due to the high content of CS in RM1 (59\%) which acted as a mineralizer, the liquid phase formation seems to take place just after the decarbonisation $\left(\left(950^{\circ} \mathrm{C}\right)\right.$. Indeed, samples of CL1 melted at temperature higher than $1100^{\circ} \mathrm{C}$. The second type of clinker CL2, from RM2 was obtained at about $1100^{\circ} \mathrm{C}$. CFA, in addition to CS, increased the content of oxides which accelerated the clinkerization process at lower temperature and CL2 started melting at temperature higher than $1150^{\circ} \mathrm{C}$. The third type of clinker CL3 from RM3 was produced at about $1150^{\circ} \mathrm{C}$. SSA and CFA, as well known, have some similar properties and CL3 melted at temperature higher than $1200^{\circ} \mathrm{C}$. The burning process depends on the conversion $\alpha$.

The conversion $\alpha$ in terms of free lime content is simply written as:

$$
\alpha=\frac{\mathrm{CaO}-\mathrm{CaO}}{\mathrm{CaO}}
$$

(Equation 1)

Where $\mathrm{CaO}_{\mathrm{i}}$ is the initial free lime content at the initial temperature $\mathrm{Ti}$ and

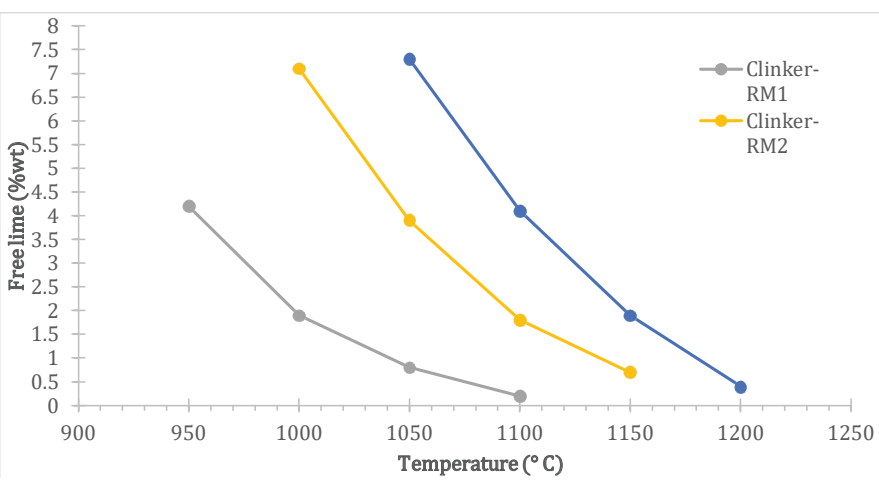

Figure 1. Burning process of raw mixes specimens during $30 \mathrm{~min}$.

$\mathrm{CaO}$ the free lime of the obtained clinker at the temperature $\mathrm{T}$.

The conversion $\alpha$ depends on the temperature and the following relations are used to describe the burning process of raw meals. According to Orfao [13]:

$$
f(\alpha)=A \int_{T_{i}}^{T} e^{\frac{-E a}{R T}} d T
$$

Where:

$$
f(\alpha)=(1-\sqrt[3]{1-\alpha})^{2}
$$

Knowing the rational approximation for the integral of the Arrhenius function, equation (2) becomes [14]:

$$
f(\alpha)=\frac{A E_{a}}{R x^{2}} e^{-x} g(x)
$$

$\mathrm{x}$ being $\frac{E a}{R T}$ and $\mathrm{g}(\mathrm{x})$ an approximative rational function

Following the fourth degree: 


$$
g(x)=\frac{x^{3}+18 x^{2}+88 x+96}{x^{4}+20 x^{3}+120 x^{2}+240 x+120}
$$

Linearizing equation (4) results equation (6):

$\ln \left(\frac{f(\alpha)}{T^{2} g(x)}\right)=\ln \left(\frac{A R}{E_{a}}\right)-\frac{E_{a}}{R T}$

(Equation 6)

The activation energy can then be determined from a linear plot (Figures 2, 3 and 4) by iterative calculations starting with $100 \mathrm{~kJ} / \mathrm{mol}$ based on previous study [9]. The spots of the plots below represent the activation energies of the three clinkerization reactions summarized in Table 6 . These values are lower than the activation energy for OPC ranged from 200 to $500 \mathrm{~kJ} / \mathrm{mol}$ [9]. Good correlations were then obtained for temperatures lower than $1200^{\circ} \mathrm{C}$ compared to $\mathrm{OPC}$ which temperature is higher than $1350^{\circ} \mathrm{C}$. Indeed, the raw mixes contained already calcium silicate which is the main compound of OPC. This contain was higher in RM1 than RM2 and RM3 leading to a low activation energy.

\section{Clinker characterization}

The chemical composition (Table 7) highlights the characteristics of the obtained clinkers which were compared to the minimum (CLPm) and maximum (CLPM) values of OPC clinker.

The fluorine (F) content (wt\%) estimated my microscopy is respectively 3.90, 0.82 and 1.61 for CL1, CL2 and CL3. The XRD patterns (Figures 5, 6 and 7) highlight the major phases identification. XRF analysis showed results within requirements limits aside from, $\mathrm{Al}_{2} \mathrm{O}_{3}$ and $\mathrm{Na}_{2} \mathrm{O}$ for all the clinkers samples. In addition, the LOI of CL1 was found slightly higher than the maximum requirement. These high contents are suspected to increase the initial hydration and decrease the compressive strength. The higher $\mathrm{Na}_{2} \mathrm{O}$ content may have an influence on the microstructure and the hydration of the obtained cements [14].

\section{$1 / T$}

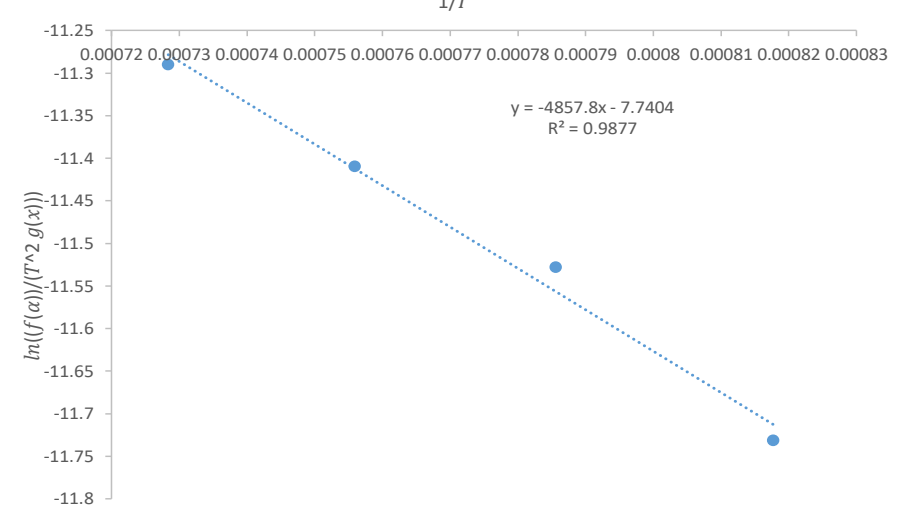

Figure 2. Equation 6's linear plot for CL1.

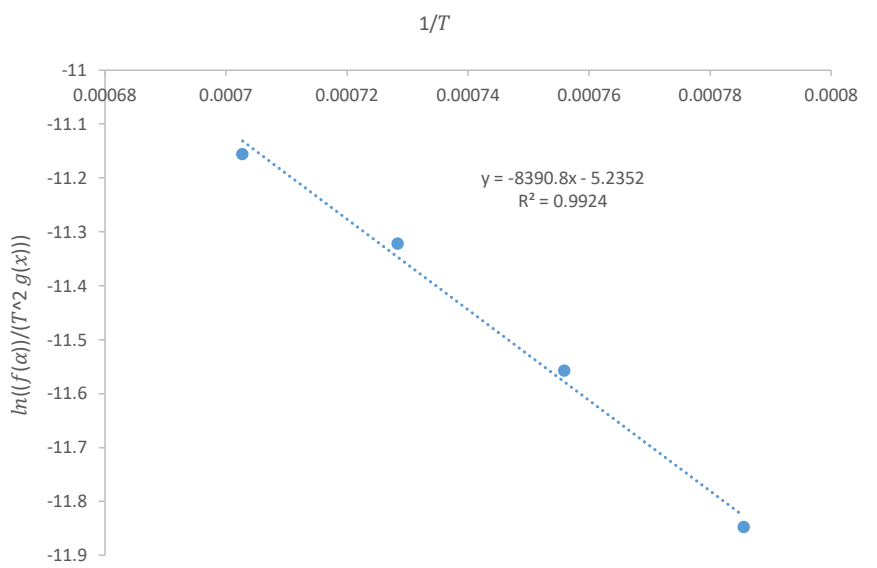

Figure 3. Equation 6's linear plot for CL2.

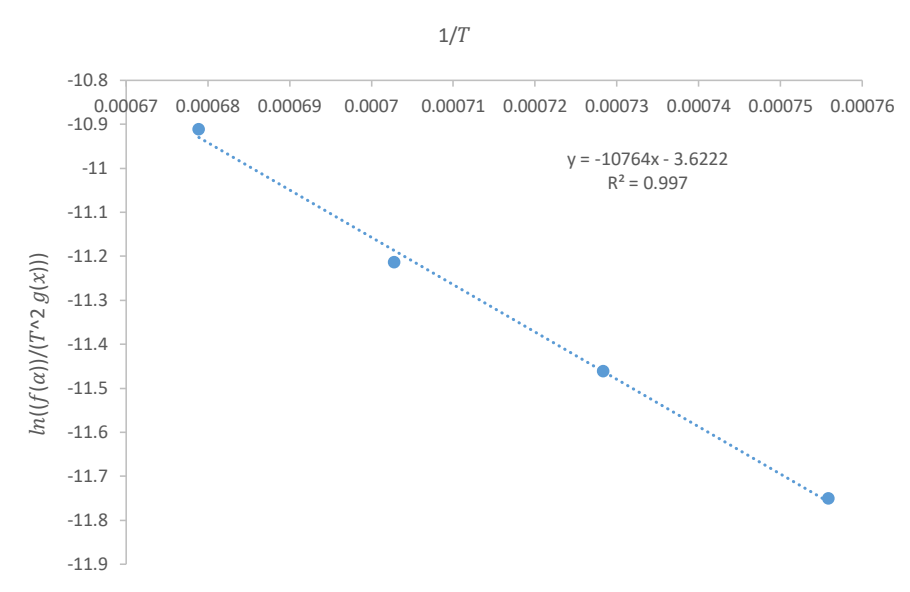

Figure 4. Equation 6's linear plot for CL3.

Table 6. Activation energy of the burning process.

\begin{tabular}{cccc}
\hline Cinker & CL1 & CL2 & CL3 \\
\hline $\mathrm{Ea}(\mathbf{k J} / \mathrm{mol})$ & 42.7 & 71.5 & 91.1 \\
\hline
\end{tabular}

Table 7. Chemical composition clinkers (\% wt).

$\begin{array}{lllllllllllllll}\text { Clinkers } & \mathrm{CaO} & \mathrm{SiO}_{2} & \mathrm{Al}_{2} \mathrm{O}_{3} & \mathrm{Fe}_{2} \mathrm{O}_{3} & \mathrm{MgO} & \mathrm{K}_{2} \mathrm{O} & \mathrm{SO}_{3} & \mathrm{Mn}_{2} \mathrm{O}_{3} & \mathrm{ZnO} & \mathrm{TiO}_{2} & \mathrm{Cl} & \mathrm{Na}_{2} \mathrm{O} & \mathrm{P}_{2} \mathrm{O}_{5} & \text { LOI }\end{array}$ \begin{tabular}{ccccccccccccccc}
\hline CL1 & 61.44 & 20.92 & 7.25 & 0.14 & 1.24 & 0.11 & 0.12 & 0.01 & 0.01 & 0.02 & 0.01 & 4.22 & 0.03 & 1.23 \\
\hline CL2 & 62.97 & 21.86 & 7.42 & 1.79 & 0.83 & 0.68 & 1.66 & 0.08 & 0.01 & 0.13 & 0.01 & 1.09 & 0.02 & 0.72 \\
\hline CL3 & 61.58 & 21.39 & 7.57 & 4.15 & 1.37 & 1.03 & 0.79 & 0.03 & 0.01 & 0.07 & 0.01 & 1.38 & 0.09 & 0.51 \\
\hline CLPm & 61.00 & 20.00 & 3.70 & 1.70 & 1.70 & 0.05 & 0.05 & 0.05 & - & 0.15 & 0.00 & 0.05 & 0.05 & 0.2 \\
\hline CLPM & 68.10 & 24.30 & 7.10 & 5.70 & 4.00 & 1.40 & 1.30 & 1.20 & - & 0.40 & 0.10 & 0.70 & 0.60 & 1.10
\end{tabular}

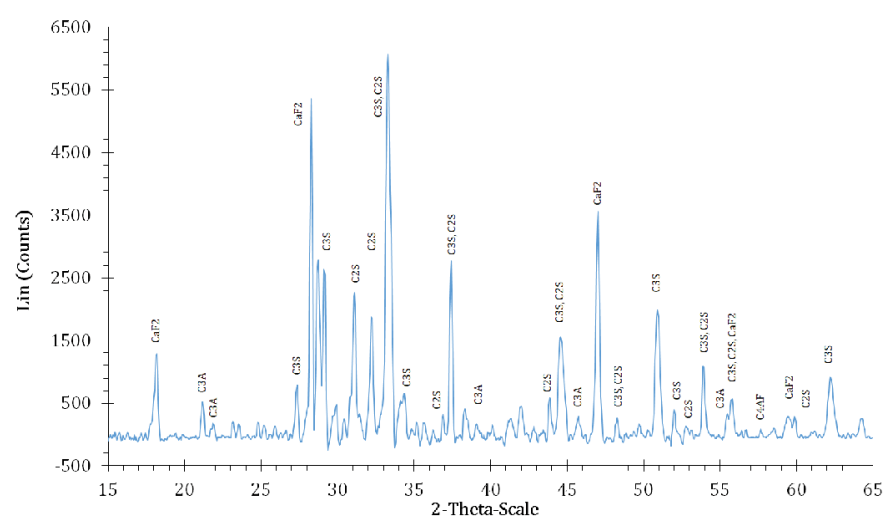

Figure 5. XRD pattern of CL1.

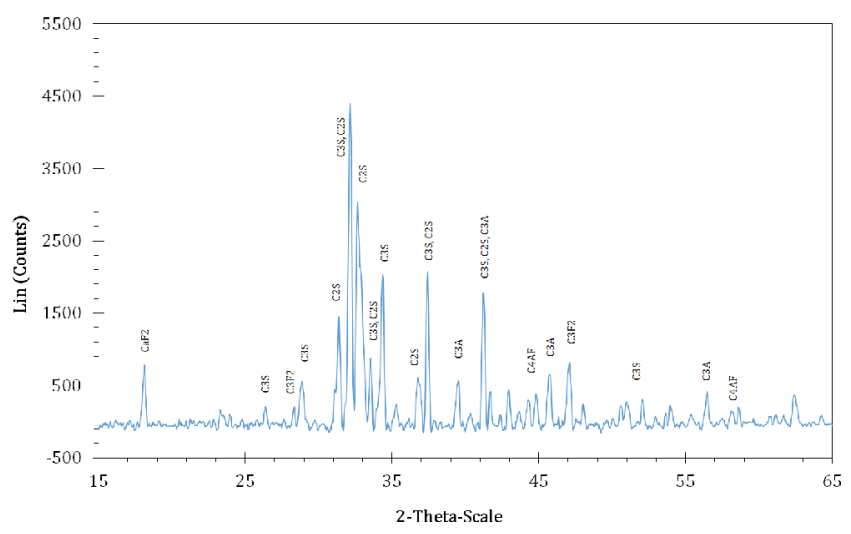

Figure 6. XRD pattern of CL2.

As well known, the difficulty in cement phases identification results in large peak overlap but also in large polymorphs co-existence. However, $\mathrm{CaF}_{2}$, in 


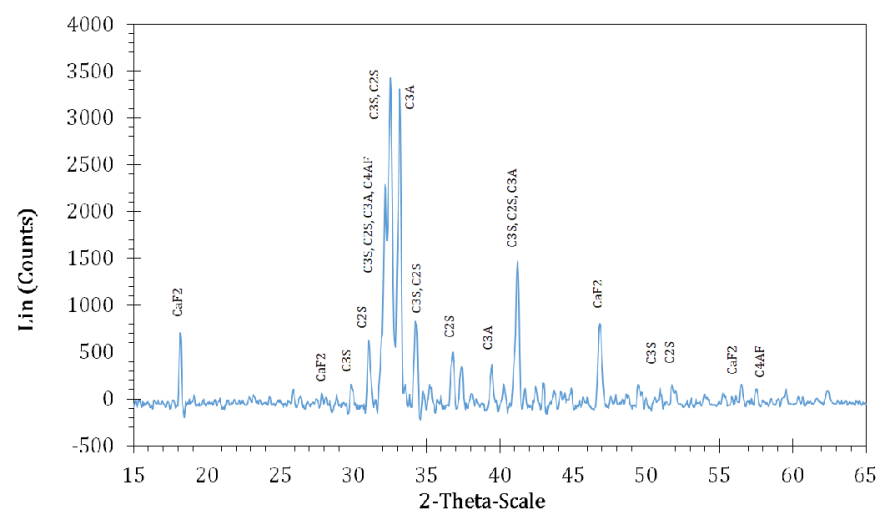

Figure 7. XDR pattern of CL3.

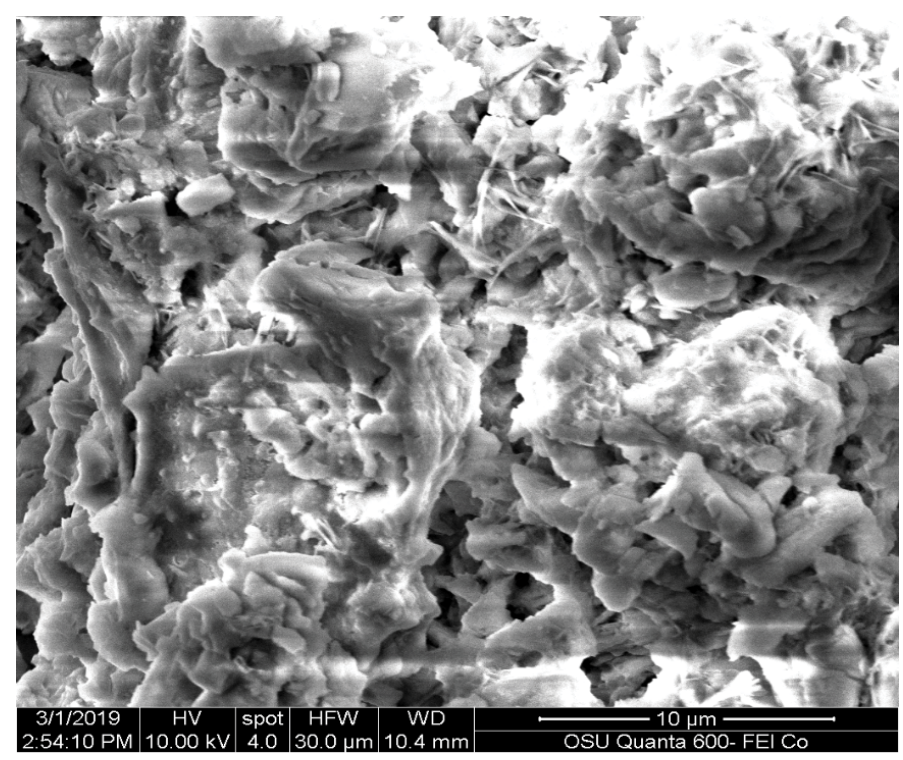

Figure 8. SEM image of $\mathrm{CL} 1-1000^{\circ} \mathrm{C}$.

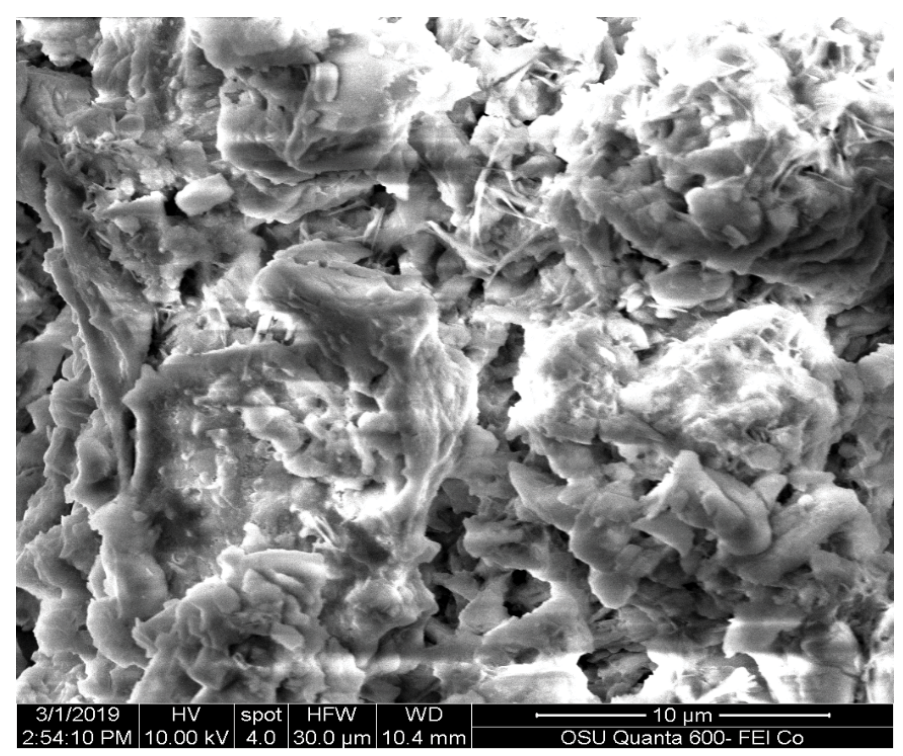

Figure 9. SEM image of $\mathrm{CL} 2-1100^{\circ} \mathrm{C}$.

addition to the main phases like $\mathrm{C}_{3} \mathrm{~S}, \mathrm{C}_{2} \mathrm{~S}$ and $\mathrm{C}_{3} \mathrm{~A}$ was detected. $\mathrm{C}_{4} \mathrm{AF}$ was found very low in RM1]. In addition to that, system like $\mathrm{C}_{3} \mathrm{~S}-\mathrm{CaF}_{2}$ and $\mathrm{C}_{2} \mathrm{~S}$ $-\mathrm{CaF}_{2}$ were supposed to form. $\mathrm{C}_{3} \mathrm{~S}$ and $\mathrm{C}_{2} \mathrm{~S}$ were found in monoclinic phase. The SEM images of the obtained clinkers are shown in Figures 8, 9 and 10 in accordance with previous studies $[15,16]$.

There are differences between the SEM images of the clinkers specimens.

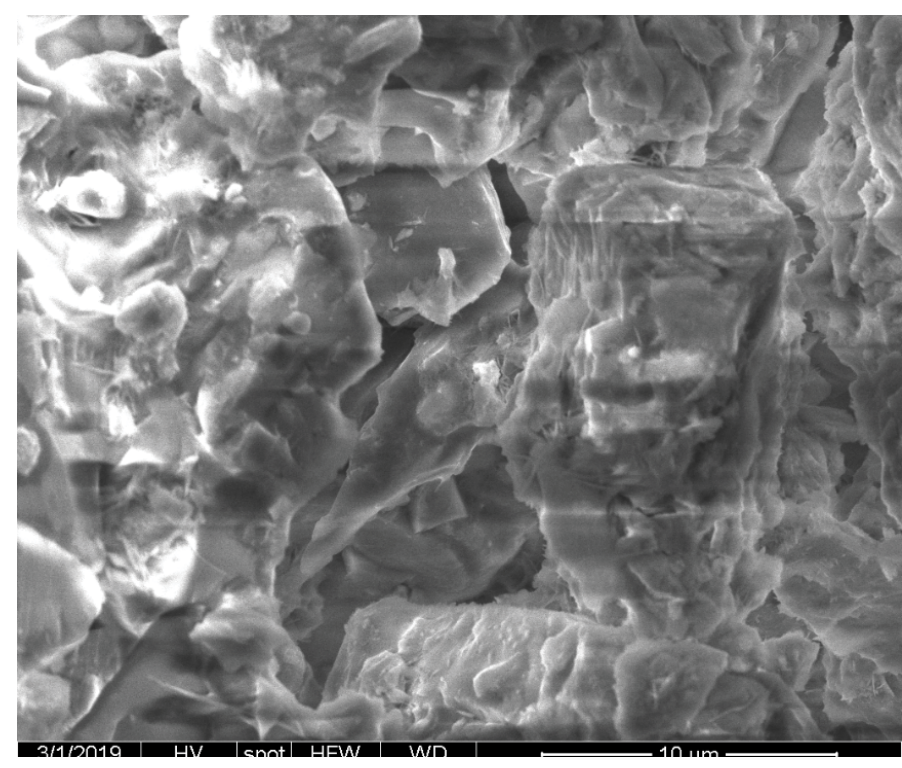

Figure 10. SEM image of $\mathrm{CL} 3-1200^{\circ} \mathrm{C}$.

Table 8. Mineralogical composition.

\begin{tabular}{ccccc}
\hline Clinkers & $\mathbf{C}_{3} \mathbf{S}$ & $\mathbf{C}_{2} \mathbf{S}$ & $\mathbf{C}_{3} \mathbf{A}$ & $\mathbf{C}_{4} \mathbf{A F}$ \\
\hline CL1 & 42.2 & 28.4 & 19.0 & 0.4 \\
\hline CL2 & 37.8 & 34.4 & 16.6 & 5.5 \\
\hline CL3 & 31.3 & 37.9 & 13.0 & 12.6 \\
\hline CLPm & 45.0 & 5.7 & 1.1 & 2.0 \\
\hline CLPM & 79.7 & 29.8 & 14.9 & 16.5 \\
\hline
\end{tabular}

Indeed, CL1 was obtained with the higher free lime content (1.9\%), then CL2 $(1.8 \%)$ and CL3 with the lowest one (0.4\%). It was difficult to well define the shapes due to the presence of impurities and the poor crystallization. The mineralogical composition is shown in Table 8. Clinkers with high belite and aluminate contents were produced from the industrial waste materials on the one hand. On the other hand, the alite and ferrite contents were remarkably lower. This is due to the clinkerization process in presence of mineralizers and fluxes such as $\mathrm{CaF}_{2}, \mathrm{Na}_{2} \mathrm{O}, \mathrm{MgO}, \mathrm{K}_{2} \mathrm{O}$ and $\mathrm{P}_{2} \mathrm{O}_{5}$ but also the high alumina and the low iron contents of the raw materials.

\section{Conclusion}

This study examined the manufacturing of cement clinker using waste materials of phosphoric acid production, wastewater treatment and coal fired power plants. Three varieties of clinker were obtained from 1000 to $1200^{\circ} \mathrm{C}$ with activation energies ranged from 42.7 to 91.1 and fluorine content from $0.82 \%$ to $3.9 \%$. There was an important presence of both mineralizers (like $\mathrm{CaF}_{2}$ ) and fluxes (like $\mathrm{Na}_{2} \mathrm{O}, \mathrm{MgO}, \mathrm{K}_{2} \mathrm{O}$ and $\mathrm{P}_{2} \mathrm{O}_{5}$ ) in the composition of the used industrial waste materials which contribute to decrease the melting point and the phases formation at lower temperatures. The XRF and XRD analyses highlighted interesting compositions as cement material. These alternative methods to produce cement dealt with resources conservation, energy efficiency and environmental protection. Replacing limestone or clay with these industrial waste materials can reduce the carbon footprint from calcination in cement industries up to $60 \%$ and the energy consumption up to $350 \mathrm{kcal} / \mathrm{kg}$ of clinker. Nonetheless, other physical tests such as setting time, compressive and flexural strength remain to be done in future work.

\section{Acknowledgement}

This study was supported by a grant from the United States Department of State, Bureau of Educational and Cultural Affairs (ECA) through the Fulbright African Senior Research Scholar Program 2018 - 2019 administered by the 
Institute of International Education's (IIE) Council for International Exchange of Scholars (CIES). The research project was conducted in Oregon State University (OSU), College of Engineering, School of Chemical, Biological and Environmental Engineering (CBEE). I'm so grateful to every person who contributed to this work.

\section{References}

1. https://www.statista.com/statistics/297845/cement-producers-capacity/

2. Gibbs, J Michael, Peter Soyka and David Conneely. " $\mathrm{CO}_{2}$ emissions from cement production" Good Practice Guidance and Uncertainty Management in National Greenhouse Gas Inventories (1996): 175-182.

3. Baidya, Rahul, Sadhan Kumar Ghosh and Ulhas V Parlikar. "Co-processing of industrial waste in cement kiln - a robust system for material and energy recovery" Procedia Environmental Sciences 31 (2016): 309 -317.

4. Guerrero Bustos, Ana Maria, S. Goni, Igor Campillo and A. Moragues. "Belite Cement Clinker From Coal Fly Ash of High Ca Content. Optimization of Synthesis Parameters" Environmental Science and Technology 38 (2004): 3209-3213.

5. Piasta, Wojciech and Monika Lukawska. "The effect of sewage sludge ash on properties of cement composites" Procedia Engineering 161 (2016): 1018-1024.

6. Vouk, Drazen, Domagoj Nakic, Nina Stirmer and Christopher Cheeseman. "Use of sewage sludge ash in cementitious materials. Reviews on Advanced Materials Science 49 (2017): 158-170.

7. Argiz, Cristina, Miguel Ángel Sanjuán, and Esperanza Menéndez. “Coal Bottom Ash for Portland Cement Production" Advances in Materials Science and Engineering 2017 (2017): 1-7.

8. Ousmane Toure, Alpha, Dame Keinde, Falilou Mbacke Sambe and Maci Joseph, et al. "Use of a Fluoride Waste in the Raw Mix for Clinker Manufacturing" AmericanEurasian Journal of Scientific Research 12 (2017): 01-06.

9. https://data.epo.org/publication-server/rest/v1.0/publication-dates/20171213/ patents/EP3255021NWA1/document.pdf

10. Ndiaye, Samba, Alpha Ousmane Toure, Falilou Mbacke Sambe, Laurent Prat, et al. "A new conversion scheme for $\mathrm{Na}_{2} \mathrm{SiF}_{6}$, an intermediate product of the fluorosilicic acid valorization. 6th International Congress on Green Process Engineering. Green product design and engineering sustainability" 2018.

11. https://www.bookdepository.com/Understanding-Cement-Nicholas-BWinter/9780957104525

12. Órfão, José JM. "Review and evaluation of the approximations to the temperature integral" AIChE 53 (2007): 2905- 2915.

13. Senum, GI and Yang RT. "Rational approximations of integral of Arrhenius function" J Them Anal 11 (1977): 445.

14. Mota, Berta, Thomas Matschei and Karen Scrivener. "Impact of $\mathrm{NaOH}$ and $\mathrm{Na}_{2} \mathrm{SO}_{4}$ on the kinetics and microstructural development of WPC hydration" Cement and Concrete Research 108 (2018): 172-185.

15. Aloui, Tahar and Fredj Chaabani. "Tunisian Neogene Sand. Used in Portland White Cement" American Ceramic Society Bulletin 86 (2007): 8.

16. Stutzman, Paul E, Pan Feng, and Jeffrey W Bullard. "Phase Analysis of Portland Cement by Combined Quantitative X-Ray Powder Diffraction and Scanning Electron Microscopy" Journal of Research of the National Institute of Standards and Technology 121 (2016)

How to cite this article: Ousmane Toure, Alpha, Nicholas Auyeung, Falilou Mbacke Sambe and Jackson Scoot Malace, et al. "Cement Clinker based on Industrial Waste Materials." Civil Environ Eng 10 (2020): 343 doi: 10.37421/ jcce.2020.10.343 